\title{
The influence of principal leadership and teacher performance on student learning
}

\author{
Sukarni Sukarni ${ }^{1}$, Bukman Lian ${ }^{2}$, Syaiful Eddy ${ }^{2}$ \\ ${ }^{1}$ Pendidikan Anak Usia Dini Harapan Bunda, Indonesia \\ ${ }^{2}$ Universitas PGRI Palembang, Indonesia
}

\section{Article Info \\ Article history: \\ Received Jul $16^{\text {th }}, 2021$ \\ Revised Aug $11^{\text {th }}, 2021$ \\ Accepted Aug 30 $0^{\text {th }}, 2021$}

\section{Keyword:}

Leadership principal

Teacher performance

\begin{abstract}
The purpose of this study was to determine the significant effect of principal leadership and teacher performance on student learning outcomes in kindergarten, Lempuing Jaya district. The population in this study were 122 teachers with a sample of 93 teachers. The results of this study indicate that, (1). there is a significant influence of the Principal's Leadership on Teacher Performance with a value (tcount 5,552> ttable 1.99547) There is a significant effect of teacher performance on student learning outcomes with tcount 2180> ttable 1.99547) there is a significant influence of principal leadership and teacher performance on student learning outcomes with a value of fcount $15.553>$ ftable 3.29 and a significant level of $0.000<0.05$ then H0 is rejected and H1 is accepted. Vareabel Leadership can be concluded that the principal and teacher performance are simultaneously significant effect on Student Learning Outcomes in kindergarten Lempuing Jaya subdistrict Ogan Ogan Ilir.
\end{abstract}

(C) 2021 The Authors. Published by IICET.

This is an open access article under the CC BY-NC-SA license

(https://creativecommons.org/licenses/by-nc-sa/4.0

\section{Corresponding Author:}

Sukarni, S.,

Pendidikan Anak Usia Dini Harapan Bunda, Indonesia

Email: karni04sukarni@gmail.com

\section{Introduction}

Education is one of the factors that influence the print quality human resource is the teacher. Therefore, a teacher must have a good performance. The principal has a very important position so that the principal is required to have the ability and readiness to influence, encourage, invite, guide, mobilize, direct and then do something that can help achieve a predetermined goal. As an education leader, the principal has a heavy responsibility [1].

The results of Hersey's research as quoted by the Directorate of Manpower, Directorate General of PMPTK (2007: 25) show that there are 10 factors that influence a person's morale in carrying out tasks, namely: work readiness, working conditions, work organization , leadership, salary, opportunities, suggesting ideas, Opportunity to learn assignments, working hours Ease of work.

Murphy in [3] states that the success of school reform is largely determined by the teacher, because the teacher is the leader of learning, facilitator, and at the same time the center of learning initiatives. High teacher performance is a manifestation of teacher quality. This is quite important in order to achieve school goals. High performance means that teachers can function as effective and effective educators in accordance with the goals they want to achieve [1]. 
However, the problem that occurs in schools, including kindergartens, is the fact that school students have almost the same human resource abilities, namely low discipline and even low academic ability [2]. In addition, teachers teach only based on their past experiences from time to time, so they feel memorized by heart and do not want to change to new things, including learning methods.

\section{Method}

This study the authors use quantitative data, namely research that is required to use numbers, starting from data collection, interpretation of the data, and the appearance of the results . This research includes research ex post facto , according Sugiyono, (2007: 7) is the research aims to investigate the events that have occurred and then Meru juk backward to determine the factors that cause these events. The population in this study were all Kindergarten teachers in Lempuing Jaya District for the 2019/2020 academic year, totaling 122 people with a total sample of 93 kindergarten teachers and head of the Lempuinng Jaya district. Analysis was performed on all data obtained with the help of the SPSS (Statistical Program Smart Solution) Ver.2 4 For Windows software program.

\section{Results and Discussions}

The The results of the analysis vareabel description of student learning outcomes in kindergarten Lempuing Jaya subdistrict is the lowest score was 16 and the highest score was 35 . The average scores of respondents regarding the leadership of 22,71 while for the standard error of 0.642 standard deviation of 3 , 801 with the variance is 14,445 . Distribution data frequency variab el results for students at kindergarten Lempuing Jaya subdistrict obtain the results as follows : 10 students or (28,57\%) has Developing Excellent (BSB), 15 students or ( $42.86 \%$ ) had Evolving accordance Hope (BSH ) 8 students or ( $22.86 \%$ ) have started to develop $(\mathrm{MB})$ and 2 students or $(5.71 \%$ ) have not developed (BB).

$\mathrm{H}$ acyl analysis vareabel description Principal Leadership in kindergarten Lempuing Jaya subdistrict is the lowest score was 68 and the highest score is 87 . The average score of respondents on leadership for 74 , 00 while for the standard error of 0,912 standard deviation of 5,912 with a variance is 29.114. Distribution data frequency variab el Leadership Principal at TK Lempuing Jaya subdistrict obtain the results as follows : $\mathrm{N}$ use values is highest 8 respondents or $22.86 \%$, higher values are 10 respondents or $28.57 \%$, the value was there were 12 respondents or $34.28 \%$ and low scores there are 5 respondents or $14.28 \%$. The results of the analysis indicate that the principal's leadership is in good category.

$\mathrm{H}$ acyl analysis vareabel description Principal Leadership in kindergarten Lempuing Jaya subdistrict is the lowest score was 73 and the highest score is 97 . The average score of respondents regarding teacher performance of 90.00 while for the standard error of 1,001 standard deviation of 5,922 with a variance is 35.067. The frequency distribution of variable data on teacher performance in kindergarten, Lempuing Jaya district, obtained the following results : the highest score results were 6 respondents or $17,14 \%$, high scores were 12 respondents or $34,29 \%$, moderate scores were 15 respondents or $42,86 \%$ and low scores there are 2 respondents or $5.71 \%$. The results of the analysis indicate that the teacher's performance is in good category. The regression equation significance test can be presented in the table below :

Table $1<$ The Significance of the Effect of Principal Leadership (X1) on Student Learning Outcomes (Y)>

\begin{tabular}{|c|c|c|c|c|c|}
\hline \multicolumn{6}{|c|}{ Coefficients $^{a}$} \\
\hline & Unstan & ed Coefficients & $\begin{array}{c}\text { Standardized } \\
\text { Coefficients }\end{array}$ & & \\
\hline Model & B & Std. Error & Beta & $\mathrm{T}$ & Sig. \\
\hline 1 (Constant) &, 110 & 8,642 & &, 013 &, 990 \\
\hline Principal leadership &, 517 &, 093 &, 733 & 5,552 &, 000 \\
\hline Teacher Performance &, 185 & 085 & 288 & 2,180 &, 000 \\
\hline
\end{tabular}

Source: Peng elolaan Data Using SPSS 24.00

The significance value is smaller than 0.05 or $0.000<0.05$ and the value or $5.552>1.99547$ so that $\mathrm{H} 1$ is accepted and $\mathrm{Ho}$ is rejected. That is a significant difference between Kepemimpinana Principal against H acyl B elajar Students in kindergarten Lempuing Jaya subdistrict komering Ogan Ilir. The regression equation significance test can be presented in the table below : 
Table $2<$ The Significance of the Effect of Teacher Performance (X2) on Student Learning Outcomes (Y)>

\begin{tabular}{|c|c|c|c|c|c|}
\hline \multirow[b]{3}{*}{ Model } & \multicolumn{3}{|c|}{ Coefficients $^{\text {a }}$} & & \\
\hline & \multicolumn{2}{|c|}{ Unstandardized Coefficients } & $\begin{array}{c}\text { Standardized } \\
\text { Coefficients }\end{array}$ & & \\
\hline & B & Std. Error & Beta & $\mathrm{t}$ & Sig. \\
\hline 1 (Constant) &, 110 & 8,642 & &, 013 & , 990 \\
\hline Principal leadership &, 517 &, 093 &, 733 & 5,552 &, 000 \\
\hline Teacher Performance &, 185 & 085 & 288 & 2,180 &, 000 \\
\hline
\end{tabular}
Source: Peng elolaan Data Using SPSS 24.00

Values of significance smaller than 0.05 or $0.000<0.05$ and value is $2.180>1.99547$ so that $\mathrm{H} 1 \mathrm{Ho}$ accepted and rejected. That is a significant difference between teacher performance against H acyl B Students. The results of the multiple regression analysis of $\mathrm{X} 1$ and $\mathrm{X} 2$ on $\mathrm{Y}$ can be seen in the table below :

Table $3<$ The Results of the Multiple Regression Analysis X1 and X2 on Y>

\begin{tabular}{llccccc}
\hline & ANOVA $^{\text {a }}$ & & & & & \\
Model & Sum of Squares & Df & Mean Square & F & Sig. \\
1 & Regression & 242,091 & 2 & 121,045 & 15,553 &, $000^{{ }^{b}}$ \\
& Residual & 249,052 & 32 & 7,783 & & \\
$\quad$ Total & 491,143 & 34 & & &
\end{tabular}

a. Dependent Variable: Student Learning Outcomes

b. Predictors: (Constant), Teacher Performance, Principal Leadership

Source: Peng elolaan Data Using SPSS 24.00

Based on the table above, the significance value is 0.000 . Testing is done using the criteria of significance or sig with the following conditions : if the significance value $<0.05$ then $\mathrm{Ha}$ is accepted and $\mathrm{Ho}$ is rejected. If the significance value $>0.05 \mathrm{Ha}$ is rejected and $\mathrm{Ho}$ is accepted. Based on the table, the value obtained or $15.5533,29$ means that $\mathrm{Ha}$ is accepted by Ho is rejected. After calculating, it can be concluded that the significant value is less than 0,000 or $0,000<0.05$ and Fhiting $>$ Ftable so that Ha is accepted and Ho is rejected. This means that there is a significant influence between the Principal Leadership and Teacher Performance on student learning outcomes .To find out how much influence the independent variable has on the dependent variable, it can be seen simultaneously in the table below:

Table $4<$ The results of the Coefficient Test are Determined by the Influence of the Principal's Leadership (X1) on Teacher Performance (X 2 ) on Student Learning Outcomes (Y)>

\begin{tabular}{lcccc}
\hline & & \multicolumn{3}{c}{ Model Summary } \\
Model & $\mathrm{R}$ & R Square & Adjusted R Square & Std. Error of the Estimate \\
1 &, $702^{\text {a }}$ &, 493 &, 461 & 2,790
\end{tabular}

a. Predicts : (Constant), Teacher Performance, Principal Leadership

Source: Peng elolaan Data Using SPSS 24.00

More explanation:

1. $\mathrm{R}=0.702$, which means that the variable Principal Leadership (X1) and Teacher Performance (X2) on Student Learning Outcomes (Y) has a STRONG relationship.

2. $\mathrm{R} 2=0.493$, which means $49.3 \%$ Principal Leadership variable (X1) and the Teacher Performance (X2) affect Student Learning Outcomes (Y) (100 - 49.3\%) 50.7\% influenced by other variables not included in this research.

3. Standard Error of Estimated (standard deviation) which means to measure the variation of the predicted value. The standard deviation in this variable is 2.790 , which means the smaller the standard deviation the better the model. From the results of the summary model output table above, the $\mathrm{R}$ number is 0.702 .

4. With the results of the $\mathrm{R}$ value of 0.702 , it can be concluded that there is a STRONG influence between the Leadership of Sekilah Head and Teacher Performance on Student Learning Outcomes.

5. The value of the $\mathrm{R}$ Square value is 0,461 or $46.1 \%$ while $53.9 \%$ is influenced by other factors not included in this research. 
6. Principal leadership has an influence on Student Learning Outcomes of $0.000<0.05$. Scor known minimum of 68 and a highest score sbesar 87 with a mean score of 74.00 while for the standard error of 0,912 , the standard deviation of 5,912 with a variance is 29.114 .

Furthermore, it is known that the value of $\mathrm{T}$ count is greater than $\mathrm{T}$ table $(5,552>1,99547)$, so $\mathrm{H} 0$ is rejected and $\mathrm{H} 1$ is accepted, so the hypothesis which says there is an influence of the Principal's Leadership on Student Learning Outcomes is partially accepted. The value of Constant is 11.088 , meaning that if there is no change in the pareabel of the Principal's Leadership and Teacher Performance (X1 and X2 values are 0) then the Student Learning Outcomes in Kindergarten, Lempuing Jaya District, Ogan Komering Ilir Regency are 11.088 .

Yuliati (2018) argues that the success and failure of subordinates is a direct reflection of the success or failure of a leader. [7]; Liskayani et al, 2019; [8] The principal is one of the driving forces for the school to realize the vision, mission, goals and objectives of the school through program programs that are implemented in a planned and gradual manner.

The value of $t$ is greater than $t$ table $(2.180>1.99547)$, so $\mathrm{H} 0$ is rejected and $\mathrm{H} 2$ is accepted, so the hypothesis which says there is an effect of teacher performance on student learning outcomes is partially accepted. Furthermore, it is known that the minimum score is 73 and the highest score is 97 . The average score of respondents regarding the leadership of the 90,00 while for the standard error of 1,001 standard deviation of 5,922 with a variance is 35.067 .

The value of the Principal Leadership Regression coefficient is 10.517, meaning that if the Principal Leadership variable (X1) increases by $1 \%$, assuming the Teacher Performance variable (X2) and the coefficient (a) is 0 (zero) then the Student Learning Outcomes in Kindergarten, Lempuing Jaya District, Ogan District Komering Ilir amounted to 10,517. This shows that the Principal Leadership variable provided has a positive contribution to Student Learning Outcomes, so that the Principal Leadership in Kindergarten in Lempuing Jaya District, Ogan Komering Ilir District, has also increased .

Based on the test results at the Fcount value of 15.553 with an Ftable value of 3.29 so that the Fcount value $>$ Ftable and a significant level of $0.000<0.05$ then $\mathrm{H} 0$ is rejected and $\mathrm{H} 1$ is accepted. It can be concluded that the variables of Principal Leadership (X1) and Teacher Performance (X2) simultaneously have a significant effect on Student Learning Outcomes in Kindergarten, Lempuing Jaya District, Ogan Komering Ilir Regency.

The teacher performance regression coefficient value is 10.185 , which means that if the teacher performance variable (X2) increases by $1 \%$ with the assumption that the Principal Leadership variable (X1) and the coefficient (a) is 0 (zero), the Student Learning Outcomes in Kindergarten, Lempuing Jaya District, Ogan District Komering Ilir amounted to 10,517. This shows that the teacher performance variables provided contribute positively to student learning outcomes, so that the greater the teacher performance results, the more student learning outcomes in kindergarten, Lempuing Jaya subdistrict, Ogan Komering Ilir district, soar student learning outcomes.

[1] States that the influence of principal leadership and teacher performance has a positive and significant effect on student learning outcomes at public high schools throughout the city [9] also argues that some teachers also argue that students in the teaching and learning process are not enthusiastic about taking lessons, students tend to be passive in accepting explanations from the teacher.

\section{Conclusions}

There is a Significant Effect Between Principal Leadership Against The results of Student Learning Amounting to $41,8 \%$, and Influence Significant Results Between Teacher Performance Against Student Jaya Amounting to $44.3 \%$ ", and there is a significant influence jointly between school leadership and teacher performance towards Student Learning Outcomes in T K Lempuing Jaya District amounted to $49.3 \%$ and $50.7 \%$ influenced by other factors not included in this research. The principal must further motivate each teacher to be more active in developing education and to become professional teachers. For schools, it is expected that they can increase motivation for teacher performance, for example by giving appreciation to teachers who have contributed to improving student learning outcomes.

A big thank you to the head of the PAUD Hrapan Bunda School, Lempuing Jaya District, Ogan Komering Ilir Regency, the Chancellor of the PGRI Palembang University, the PLT Director of the PGRI Palembang University Postgraduate Program and the Chair of the PGRI Palembang University Education Management 
Masters Study Program for helping in the completion of this journal which is a product of the Thesis . Then thanks to friends of the PGRI Palembang University Postgraduate students and all those who have helped write and publish this journal.

\section{References}

Aritonang, K. (2008). Minat dan Motivasi dalam Meningkatkan Hasil Belajar Siswa. Jurnal Pendidikan Penabur Andriani, S., Kesumawati, N., \& Kristiawan, M. (2018). The Influence of the Transformational Leadership and Work Motivation on Teachers Performance. International Journal of Scientific \& Technology Research, 7(7). No.10/Tahun ke-9/Juni 2010. Diakses 10 April 2016.

Endah Listyasari. (2012). Pengaruh Kepemimpinan Kepala Sekolah dan Kinerja Guru Terhadap Hasil Belajar Siswa Di SMA Negeri Se-Kota Tasikmalaya (Dalam Mata Pelajaran Penjas Thun 2012. Jurnal Unsil.ac.id.

E. Mulyasa. (2008). Menjadi guru profesional menciptakan pembelajaran kreatif dan menyenangkan. Bandung : Remaja Rosdakarya.

DNAO Putri, Lian Bukman dan Pramika Depi. (2019). Pengaruh Model Pembelajaran Concept Attainmant Terhadap Hasil Belajar Siswa pada Mata Pelajaran Ekonomi di SMA Srijaya Negara Palembang. Jurnal Neraca.vol 3 no 1.

Direktorat Ketenagaan - Dirjen PMPTK. (2007).Kepemimpinan Kepala Sekolah Dalam Meningkatkan Sumber Daya Manusiadi Sekolah Dasar. Jakarta: Depdiknas.

Depdiknas. (2005). Pembinaan Profesionalisme Tenaga pengajar (PengembanganProfesionalisme Guru). Jakarta: Direktorat Jenderal Pendidikan dasar dan Menengah Direktorat Pendidikan Lanjutan Pertama Depdiknas.

Kartini, Ahmad, S., \& Eddy, S. (2020). Pengaruh Gaya Kepemimpinan Kepala Sekolah dan Komunikasi Interpersonal Terhadap Kinerja Guru. Journal Of Education Research, 1(3), 290-294.

Sugiyono. (2013). Metode Penelitian Kuantitatif, Kualitatif dan R\&D. Bandung: Alfabeta.CV

Yuliati, E. (2018). Kepemimpinan Transformational Kepala Sekolah. Salatiga: Griya Media. 